\title{
Electrodeposition, Characterization, and Corrosion Stability of Nanostructured Anodic Oxides on New Ti-15Zr-5Nb Alloy Surface
}

\author{
Jose M. Calderon Moreno, Cora Vasilescu, Silviu Iulian Drob, Monica Popa, Paula Drob, \\ and Ecaterina Vasilescu
}

Romanian Academy, Institute of Physical Chemistry "Ilie Murgulescu," Splaiul Independentei 202, 060021 Bucharest, Romania

Correspondence should be addressed to Cora Vasilescu; cvasilescu@chimfiz.icf.ro

Received 11 February 2013; Accepted 20 March 2013

Academic Editor: Mohamed Bououdina

Copyright (c) 2013 Jose M. Calderon Moreno et al. This is an open access article distributed under the Creative Commons Attribution License, which permits unrestricted use, distribution, and reproduction in any medium, provided the original work is properly cited.

\begin{abstract}
A new Ti-15Zr-5Nb alloy with suitable microstructure and mechanical properties was processed by galvanostatic anodization in $0.3 \mathrm{M} \mathrm{H}_{3} \mathrm{PO}_{4}$ solution and a continuous nanostructured layer of protective $\mathrm{TiO}_{2}$ oxide was electrodeposited. The obtained anatase oxide layer has a nanotubes-like porosity (SEM observations) and contains significant amount of phosphorus in phosphotitanate compound embedded in the oxide lattice (Raman, FT-IR, SEM, and EDX analysis). This layer composition can stimulate the formation of the bone and its porosity can offer a good scaffold for bone cell adhesion. The electrochemical behaviour, corrosion stability, and variations of the open circuit potentials, $E_{\mathrm{oc}}$, and corresponding open circuit potential gradients, $\Delta E_{\mathrm{oc}}$, for 1500 soaking hours in Ringer solutions of 3.21, 7.58, and $8.91 \mathrm{pH}$ values were studied. The anodized layer was more resistant, stable (from EIS spectra), and was formed from an inner barrier insulating layer that assures the very good alloy corrosion resistance and an outer porous layer that provides the good conditions for cell development. The nanostructured alloy has higher corrosion stability, namely, a more reduced quantity of ions released and a lower toxicity than that of the bare one. The monitoring of $E_{\mathrm{oc}}$ and $\Delta E_{\mathrm{oc}}$ showed the enhancement and stabilizing of the long-term passive state of the anodized alloy and, respectively, no possibility at galvanic corrosion.
\end{abstract}

\section{Introduction}

Titanium and its alloys are used as orthopaedic and dental implants due to their good mechanical and anticorrosive properties and biocompatibility. However, it is an increasing necessity to obtain new alloys with a low elastic modulus, close to that of the human bone (10-40 GPa) [1], and based only on nontoxic, nonallergic, biocompatible elements as $\mathrm{Zr}$, $\mathrm{Nb}$, and $\mathrm{Ta}[2,3]$. Titanium alloys containing these biocompatible metals are relatively bioinert and the implant-bone integration is a longer process than that of the bone healing.

The alloy bioactivity depends on its surface chemistry, topography, porosity, and roughness; a rough surface enhances the contact with the bone and improves the bioactive bone-binding activity. Thus, surface treatments that form thin or thick, uniform, resistant, porous, rough layers on the implant surface and also incorporate constituent elements of the human bone (calcium and phosphorus) or protective compounds (phosphates, hydroxyapatite) are applied in the last time [4-7]. Electrochemical anodic or cathodic deposition of the oxide layers is an important, cheap, efficient method to increase the protective and osseointegrative properties of the titanium alloys; oxide nanotubes are formed on the alloy surface being a good matrix for bone cell colonization [8].

Electrochemical potentiostatic anodization technique was performed on Ti and its alloys in different solutions, and controlling the polarization parameters, the bioactive $\mathrm{TiO}_{2}$ nanotubes were obtained enhancing the alloy biocompatibility [9-14].

Electrochemical galvanostatic anodization method was accomplished on $\mathrm{Ti}$ and some of its binary, ternary, and 
quaternary alloy surfaces using especially acidic solutions; varying solution composition, $\mathrm{pH}$, temperature, and anodizing parameters, biofunctionalized surfaces were realized [1517].

To obtain a biocompatible surface is a complex problem because must be an alloy containing only nontoxic, nonallergic, biocompatible elements, having very good mechanical properties and then must be taken into consideration the most favorable method adapted for the improvement of its bioactivity.

In this paper, a new Ti-15Zr-5Nb alloy was elaborated to satisfy the most important requirements of an implant material; this alloy (containing only nontoxic and nonallergic elements) has an $\alpha+\beta$ microstructure, type Widmanstatten, a low Young's modulus $(82.69 \mathrm{GPa})$, and a good correlation between its mechanical properties and corrosion resistance. Its biocompatibility and anticorrosive properties were enhanced by galvanostatic anodization in $0.3 \mathrm{M} \mathrm{H}_{3} \mathrm{PO}_{4}$ (orthophosphoric acid) solution assuring the formation of a continuous nanostructured layer of protective $\mathrm{TiO}_{2}$ oxide; this layer incorporated phosphorus as phosphotitanate $\left(\mathrm{P}_{2} \mathrm{O}_{5}{ }^{2-}\right)$ ions, increasing the alloy bioactivity.

\section{Experimental Details}

2.1. Materials. The new Ti-15Zr-5Nb alloy was obtained by vacuum, cold-crucible, semilevitation melting; alloy composition is (\%wt.) $0.011 \% \mathrm{H}_{2} ; 0.02 \% \mathrm{~N}_{2} ; 0.12 \% \mathrm{O}_{2} ; 0.052 \%$ $\mathrm{Mg} ; 0.00235 \% \mathrm{Ca} ; 0.00831 \% \mathrm{Cr} ; 0.02048 \% \mathrm{Fe} ; 0.0077 \% \mathrm{Ni}$; $0.0181 \% \mathrm{Ta} ; 14.97 \% \mathrm{Zr} ; 5.111 \% \mathrm{Nb}$; balance Ti. From as-cast ingots were cut cylindrical samples for experiments.

\subsection{Electrodeposition of the Nanostructured Oxide Layer.} Before the anodic galvanostatic processing, the samples were ground with metallographic paper till 2000 grade to eliminate any surface defects and then were ground with metallographic paper of 600 grades to assure the necessary roughness and were washed with bidistilled water. Then, the samples were ultrasonically degreased in acetone and bidistilled water (for $15 \mathrm{~min}$ ), dried in air, and fixed in a Stern-Makrides mount system. The anodic galvanostatic polarization was applied by a DC power source (MATRIX, China) that supplied current densities of $5 \mathrm{~mA} / \mathrm{cm}^{2}$ and $10 \mathrm{~mA} / \mathrm{cm}^{2}$ between the working electrode (Ti-15Zr-5Nb alloy) and auxiliary electrode $(\mathrm{Pt})$; these current densities were constantly maintained for different time periods of $15,30,45$, and $60 \mathrm{~min}$. The anodization solution was orthophosphoric acid $\left(\mathrm{H}_{3} \mathrm{PO}_{4}\right)$ of $0.3 \mathrm{M}$ and $1 \mathrm{M}$ concentrations; three processing parameters were varied: the solution concentration, current density, and time; different oxide layers were obtained and the nanostructured surface with the most favorable structural and morphological properties was selected and its electrochemical behaviour, corrosion stability, and long-term behaviour in different simulated physiological solutions were studied.

2.3. Characterization of the Nanostructured Oxide Layer. Composition of the obtained layers was verified by Raman microscopy and Fourier transform infrared (FT-IR) analysis.
Raman spectra were measured at room temperature using a LABRam Jobin Yvon (Japan) equipment. Acquisition time was $40 \mathrm{~s}$; the green line $(\lambda=514.5 \mathrm{~nm})$ of $\mathrm{Ar}^{+}$laser was used to excite Raman spectra at a power of $\sim 20 \mathrm{~mW}$. Measurements were carried out under a microscope, with a 90x microscope objective; the laser spot size was around $1-2 \mu \mathrm{m}$. Raman measurements covered the range between 100 and $1100 \mathrm{~cm}^{-1}$.

FT-IR spectra were registered as a resolution of $4 \mathrm{~cm}^{-1}$, over the frequency range from 1400 to $600 \mathrm{~cm}^{-1}$, using a spectrophotometer model Nicolet 6700 FTIR (USA). The spectra were taken from thin transparent $\left(\sim 20 \mathrm{mg} / \mathrm{cm}^{2}\right) \mathrm{KBr}$ pellets containing approximately $0.5 \% \mathrm{wt}$ samples. Pellets were prepared by compacting and vacuum pressing of an intimate mixture obtained by grinding $1 \mathrm{mg}$ of substance in $200 \mathrm{mg} \mathrm{KBr}$.

The morphology, microstructure, and elemental composition of the nanostructured electrodeposited layer were analyzed by scanning electron microscopy (SEM) using a Quanta 3D FEG apparatus (The Nederland) working at an accelerating voltage of $20 \mathrm{kV}$ and equipped with an energy dispersive X-ray (EDX) spectrometer.

2.4. Electrochemical Behaviour of Bare and Anodized Ti-15Zr$5 \mathrm{Nb}$ Alloys. The electrochemical behaviour of the anodized Ti-15Zr-5Nb alloy was examined in comparison with the bare alloy in Ringer solution of different $\mathrm{pH}$ values (acid $\mathrm{pH}=3.21$, obtained by $\mathrm{HCl}$ addition; neutral $\mathrm{pH}=7.58$, normal; alkaline $\mathrm{pH}=8.91$, obtained by $\mathrm{KOH}$ addition) that simulate the severe functional conditions from the human body: in the case of surgery, the $\mathrm{pH}$ decreases till $3-4$ value $[18,19]$ and must long time to come back to 7.4 value; in the case of inflammations or infections, the $\mathrm{pH}$ can increase till 9 value [20]. Ringer solution composition was $(\mathrm{g} / \mathrm{L}) \mathrm{NaCl}-6.8 ; \mathrm{KCl}-0.4 ; \mathrm{CaCl}_{2}-0.2 ; \mathrm{MgSO}_{4} \cdot 7 \mathrm{H}_{2} \mathrm{O}-$ $0.2048 ; \mathrm{NaH}_{2} \mathrm{PO}_{4} \cdot \mathrm{H}_{2} \mathrm{O}-0.1438 ; \mathrm{NaHCO}_{3}-1.1$; glucose-1. The working temperature was $37^{\circ} \pm 1^{\circ} \mathrm{C}$.

The electrochemical behaviour was studied by cyclic potentiodynamic polarization method and electrochemical impedance spectroscopy (EIS).

The cyclic potentiodynamic measurements were applied beginning from $-0.5 \mathrm{~V}$ till $+2 \mathrm{~V}$ (versus saturated calomel electrode, SCE) at a scan rate of $1 \mathrm{mV} / \mathrm{s}$. Voltalab 80 equipment (Radiometer, France) with its VoltaMaster 4 program was used. From voltammograms, the main electrochemical parameters that characterize the bare and anodized $\mathrm{Ti}$ $15 \mathrm{Zr}-5 \mathrm{Nb}$ alloy behaviour were determined: $E_{\text {corr }}$-corrosion potential (like zero current potential); $E_{p}$-passivation potential (the potential value at which the current becomes constant); $\left|E_{\text {corr }}-E_{p}\right|$-tendency to passivation (low values show a rapid, easy passivation); $\Delta E_{p}$-passive potential range (potential range for constant current, plateau range; larger potential range proves a more resistant material); $i_{p}-$ passive current density (lower values indicate a more protective passive layer).

EIS measurements were carried out at open circuit potential- $E_{\text {oc }}$ with the same VoltaLab 80 equipment; Nyquist and Bode spectra were recorded applying sine wave of $5 \mathrm{mHz}$ in the frequency range from $100 \mathrm{mHz}$ to $100 \mathrm{kHz}$, with 7 
points per decade. The electric equivalent circuit was fitted using nonlinear least square ZVIEW program.

2.5. Corrosion Stability of Bare and Anodized Ti-15Zr-5Nb Alloys. Linear polarization measurements were performed for $\pm 50 \mathrm{mV}$ around the open circuit potential at a scan rate of $1 \mathrm{mV} / \mathrm{s}$, using the same Voltalab 80 equipment. From Tafel representation, the VoltaMaster 4 program directly supplied the values of the corrosion current density $-i_{\text {corr }}$, corrosion rate $-V_{\text {corr }}$, and polarization resistance $-R_{p}$; the total quantity $\left(\mathrm{ng} / \mathrm{cm}^{2}\right)$ of ions released in biofluid was calculated $[21,22]$ as

$$
\text { Ion release }=1.016 \cdot V_{\text {corr }} \cdot 10^{5} \text {, }
$$

where $V_{\text {corr }}=$ corrosion rate in $\mathrm{mm} /$ year.

2.6. Long-Term Behaviour of Bare and Anodized Ti-15Zr$5 \mathrm{Nb}$ Alloys. The long-term behaviour of bare and anodized alloys was monitored by the measurements of the open circuit potentials $-E_{\mathrm{oc}}$ (with a performing Hewlett-Packard multimeter) at regular time periods, till 1500 soaking hours in Ringer solutions. The shift of $E_{\mathrm{oc}}$ to more positive values shows the increase of the thickness of oxide passive film and lower corrosion rate [23]. The decrease of $E_{\text {oc }}$ value suggests dissolution processes at the interface and its subsequent increase, the formation of new oxide layer [23]. Also, taking into consideration that the human biofluid $\mathrm{pH}$ can vary from acid to alkaline values, different $\mathrm{pH}$ values can appear along the implant surface; thus, $E_{\mathrm{oc}}$ will have various values on different zones of the implant, producing potential gradients$\Delta E_{\text {oc }}$ - that can initiate galvanic cells and can accelerate the implant corrosion; simulating these conditions, the following gradients were calculated [24-26]:

$$
\begin{aligned}
& \Delta E_{\mathrm{oc} 1}(\mathrm{pH})=E_{\mathrm{oc}}^{\mathrm{pH}=3.21}-E_{\mathrm{oc}}^{\mathrm{pH}=7.58}, \\
& \Delta E_{\mathrm{oc} 2}(\mathrm{pH})=E_{\mathrm{oc}}^{\mathrm{pH}=3.21}-E_{\mathrm{oc}}^{\mathrm{pH}=8.91}, \\
& \Delta E_{\mathrm{oc} 3}(\mathrm{pH})=E_{\mathrm{oc}}^{\mathrm{pH}=7.58}-E_{\mathrm{oc}}^{\mathrm{pH}=8.91} .
\end{aligned}
$$

Also, the time variations of $\Delta E_{\mathrm{oc}}$ values were registered with the aim of evaluating the possible susceptibility to galvanic or local corrosion.

\section{Results and Discussion}

3.1. Characterization of the Alloy Nanostructured Surface. Composition of the electrodeposited layer was determined from Raman spectra and FT-IR analysis. The morphology, microstructure, and elemental composition of the surface layer were analyzed by SEM and EDX methods.

3.1.1. Characterization of the Alloy Surface Galvanostatically Anodized in $0.3 \mathrm{M} \mathrm{H}_{3} \mathrm{PO}_{4}$ for $45 \mathrm{~min}$. at a Current Density of $10 \mathrm{~mA} / \mathrm{cm}^{2}$. SEM observations of the alloy surface after galvanostatic anodization (Figure 1) revealed the formation of a layer showing two hierarchical features: hill-like protuberances with a typical width between 5 and $10 \mu \mathrm{m}$ (Figure 1(a)), where the layer is locally thicker, and nanotube-like porosity with diameters in the one to a few hundred manometers (Figure 1(b)). The chemical analysis by EDX determined that the nanostructured layer contains significant amount of $\mathrm{P}$ and $\mathrm{O}$, as well as the constituent alloy elements (Figure 2).

Raman microspectroscopy is especially suitable for the analysis of the presence of oxides $[27,28]$ and/or phosphates, [29-31] even if present as nanocrystalline or secondary phases in surface layers, difficult to detect by other methods. Raman measurements (Figure 3) clearly showed the existence of titanium oxide with anatase-like structure, indicated by the existence of a strong band at $149 \mathrm{~cm}^{-1}$, coincident with the main $E_{g}$ vibrational band of anatase. The significant shift from reported values at $\sim 142-145 \mathrm{~cm}^{-1}[27,28]$ of different anatase nanoparticles with dimensions between 12 and $30 \mathrm{~nm}$ and the width of the main band clearly indicate smaller dimensions of the anatase nanocrystallites nucleated in the anodized surface layer. Besides, the additional spectral features reveal a substantial modification of the crystalline structure of anatase during anodization in $\mathrm{H}_{3} \mathrm{PO}_{4}$ : the wide bands centered at $\sim 400 \mathrm{~cm}^{-1}$ and at $\sim 600 \mathrm{~cm}^{-1}$ cannot be unambiguously matched with the secondary features of anatase at $395 \mathrm{~cm}^{-1}\left(B_{1 g}\right)$ and $638 \mathrm{~cm}^{-1}\left(E_{g}\right)$ [27, 28], while the $\left(A_{1 g}\right)$ band at $515 \mathrm{~cm}^{-1}$ is not present and the $E_{g}$ band at $195 \mathrm{~cm}^{-1}$ is masked by the wide main band. Different authors have reported similar wide Raman bands in titania modified layers containing phosphorus, either as phosphate $\left(\mathrm{PO}_{4}{ }^{3-}\right)$ or as pyrophosphate $\left(\mathrm{P}_{2} \mathrm{O}_{7}{ }^{4-}\right)$ groups, embedded in the $\mathrm{O}-\mathrm{Ti}(\mathrm{Nb})-\mathrm{O}$ oxidized surface layer $[32,33]$ and caused by modification of Ti-O-Ti bonds into $\mathrm{P}-\mathrm{O}-\mathrm{Ti}$ and $\mathrm{P}-\mathrm{O}-$ $\mathrm{P}$ bonds in the oxide lattice. Raman analysis of the anodized surface, on the other hand, found no evidence of the presence of the $\mathrm{PO}_{4}{ }^{3-}$ group characteristic main vibrational band at $\sim 1000 \mathrm{~cm}^{-1}$ [29-31].

Because the sensitivity of Raman method for $\mathrm{Ti}-\mathrm{O}$ bonding is significantly higher than that for phosphate bonds, we used FT-IR vibrational spectroscopy to investigate the presence of phosphate groups, in order to complete the compositional analysis of the electrodeposited films. The two wide bands, centered at $\sim 800 \mathrm{~cm}^{-1}$ and $1100 \mathrm{~cm}^{-1}$, detected by FT-IR (Figure 4 ) can only be attributed to the $v_{3}$ bending mode of the $\mathrm{P}-\mathrm{O}-\mathrm{P}$ bonds in phosphotitanate glass oxide, due to the incorporation of $\mathrm{P}^{5+}$ ions $[33,34]$ into the oxide coating, promoted by the acidic conditions.

We can conclude that the layer electrodeposited in $0.3 \mathrm{M}$ $\mathrm{H}_{3} \mathrm{PO}_{4}$ solution is formed by anatase oxide that contains phosphorus as $\mathrm{P}_{2} \mathrm{O}_{7}{ }^{4-}$ ion in phosphotitanate compound, phosphorus being the main inorganic component of the human bone thus stimulating the formation of bone [35]. Also, this nanolayer has a nanotube-like porosity that can provide a good scaffold for the bone cell development [35].

3.1.2. Characterization of the Alloy Surface Galvanostatically Anodized in $1 \mathrm{M} \mathrm{H}_{3} \mathrm{PO}_{4}$ for $45 \mathrm{~min}$. at a Current Density of $10 \mathrm{~mA} / \mathrm{cm}^{2}$. The analysis of the galvanostatic anodization $\mathrm{Ti}-$ $15 \mathrm{Zr}-5 \mathrm{Nb}$ alloy surface by vibrational Raman (Figure 5) and 


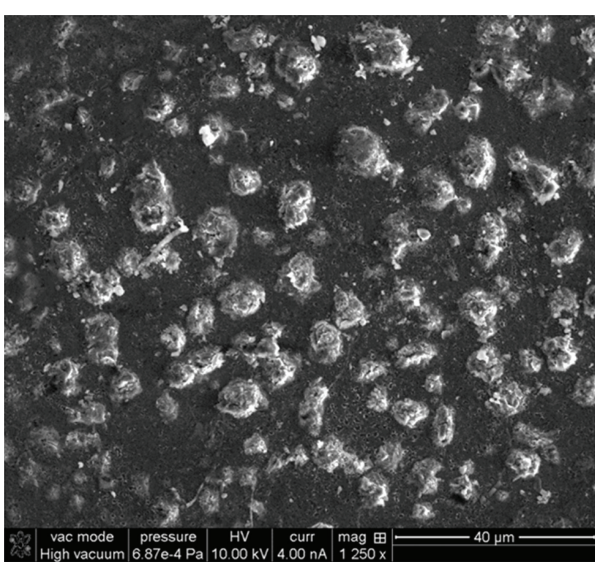

(a)

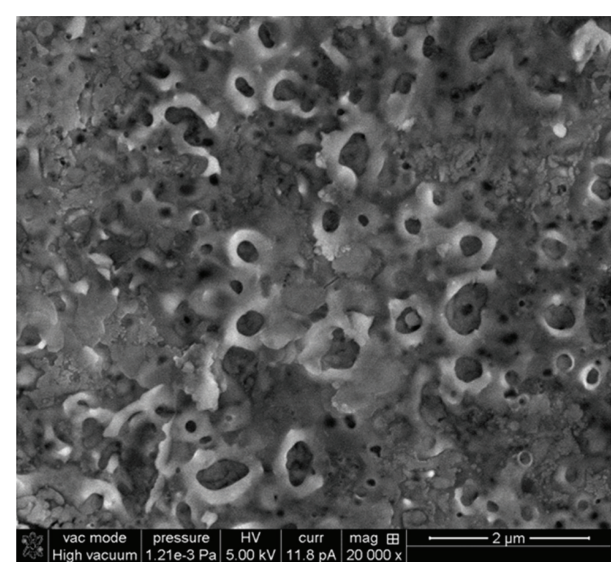

(b)

FIGURE 1: SEM micrographs of Ti-15Zr-5Nb alloy surface galvanostatically anodized in $0.3 \mathrm{M} \mathrm{H}_{3} \mathrm{PO}_{4}$ solution for $45 \mathrm{~min}$. at $10 \mathrm{~mA} / \mathrm{cm}^{2}$ : (a) hill-like protuberances; (b) nanotube-like porosity.

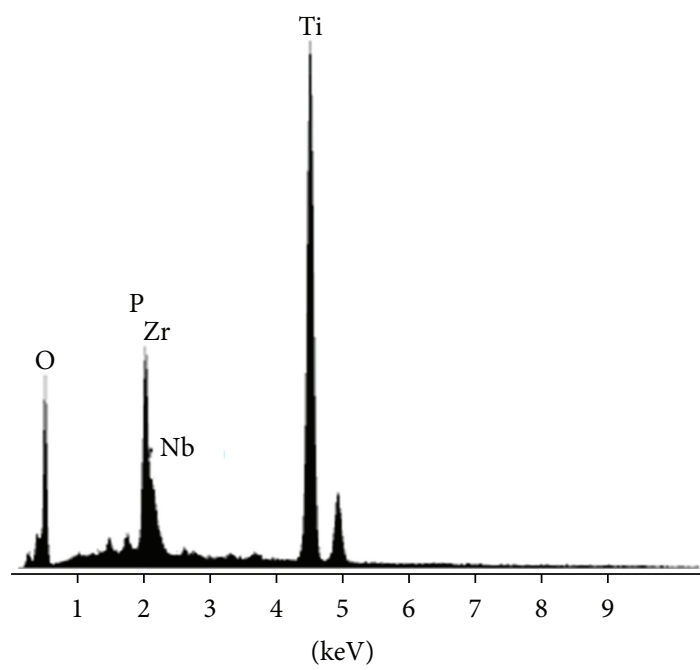

FIGURE 2: EDX spectrum of Ti-15Zr-5Nb alloy surface galvanostatically anodized in $0.3 \mathrm{M} \mathrm{H}_{3} \mathrm{PO}_{4}$ solution for $45 \mathrm{~min}$. at $10 \mathrm{~mA} / \mathrm{cm}^{2}$.

FT-IR (Figure 6) spectroscopies detected the same composition of the electrodeposited layer, namely, $\mathrm{TiO}_{2}$ anatase oxide, modified with phosphorus as pyrophosphate bonds in titania-based oxide.

SEM micrographs (Figure 7) of the sample processed electrochemically in $1 \mathrm{M} \mathrm{H}_{3} \mathrm{PO}_{4}$ showed the deposition of loose aggregates (Figure 7(b)) of submicron sized particles on top of the porous layer (Figure 7(a)). The additional features have the same composition of the continuous passivating layer, as determined from the EDX analysis (Figure 8). It results in the fact that in $1 \mathrm{M} \mathrm{H}_{3} \mathrm{PO}_{4}$ solution was obtained a nanolayer with lower microstructural properties.

From the previous experimental results, it appears that the most favorable properties of $\mathrm{Ti}-15 \mathrm{Zr}-5 \mathrm{Nb}$ alloy surface were obtained by the galvanostatic anodization in $0.3 \mathrm{M}$ $\mathrm{H}_{3} \mathrm{PO}_{4}$ solution for $45 \mathrm{~min}$. at $10 \mathrm{~mA} / \mathrm{cm}^{2}$. The electrochemical behaviour, corrosion stability, and long-term behaviour

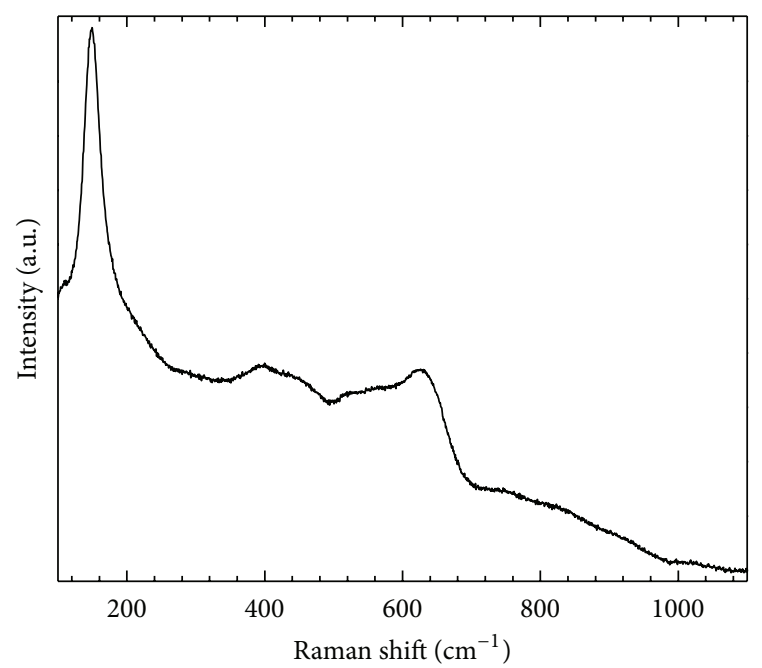

Figure 3: Raman spectrum of Ti-15Zr-5Nb alloy surface galvanostatically anodized in $0.3 \mathrm{M} \mathrm{H}_{3} \mathrm{PO}_{4}$ solution for $45 \mathrm{~min}$. at $10 \mathrm{~mA} / \mathrm{cm}^{2}$.

of the alloy surface processed by this method will be studied later on (named anodized alloy).

3.2. Electrochemical Behaviour of the Bare and Anodized Alloys in Ringer Solutions of Different $p H$ Values. Electrochemical behaviour of the bare and anodized alloys in Ringer solutions of 3.21, 7.58, and $8.91 \mathrm{pH}$ values was determined from cyclic potentiodynamic and EIS measurements.

3.2.1. Electrochemical Behaviour from Cyclic Potentiodynamic Measurements. Cyclic potentiodynamic curves from Figure 9 make evident a nobler behaviour of the anodized alloy than that of the bare one, because all the electrochemical parameters (Table 1) have more favorable values $[10,15]$ : 


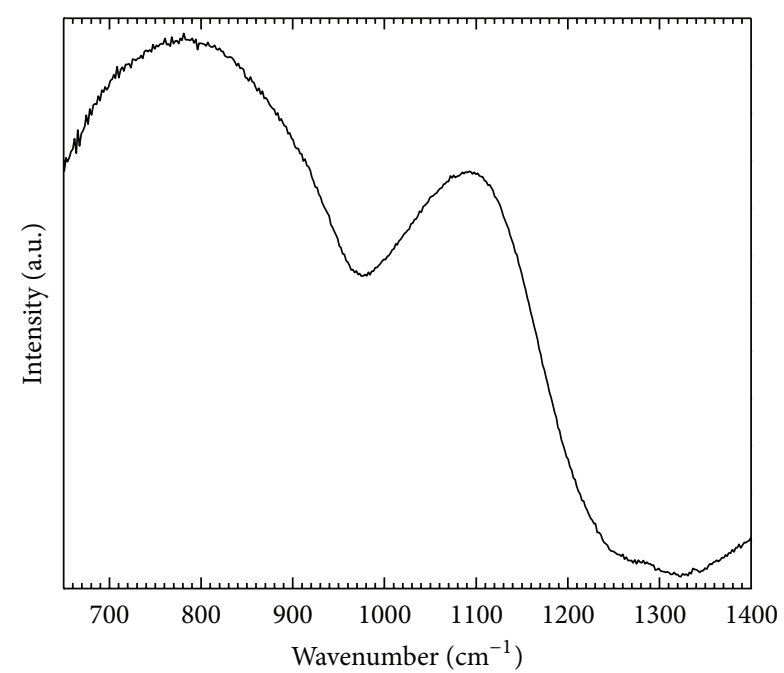

FIGURE 4: FT-IR spectrum of Ti-15Zr-5Nb alloy surface galvanostatically anodized in $0.3 \mathrm{M} \mathrm{H}_{3} \mathrm{PO}_{4}$ solution for $45 \mathrm{~min}$. at $10 \mathrm{~mA} / \mathrm{cm}^{2}$.

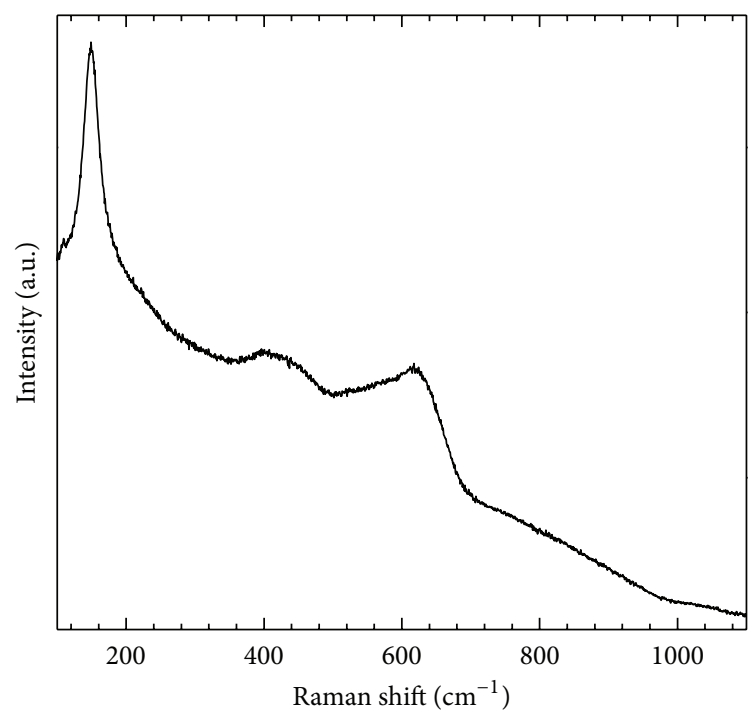

FIGURE 5: Raman spectrum of Ti-15Zr-5Nb alloy surface galvanostatically anodized in $1 \mathrm{M} \mathrm{H}_{3} \mathrm{PO}_{4}$ solution for $45 \mathrm{~min}$. at $10 \mathrm{~mA} / \mathrm{cm}^{2}$.

(i) corrosion, $E_{\text {corr }}$ and passivation, $E_{p}$ potentials have more electropositive values and passive current densities, $i_{p}$ are lower, showing a more protective, more resistant nanostructured layer on the anodized alloy surface [23],

(ii) tendency to passivation, $\left|E_{\text {corr }}-E_{p}\right|$, has lower values indicating that the processed alloy is more easily, more rapidly passivated, as a result of the existence of the electrodeposited nanolayer that improves the protective properties of the native passive layer by its thickening $[23,25]$.

In acid and alkaline Ringer solutions, the main electrochemical parameters presented slightly more unfavorable values both for the bare and the anodized alloys due to the

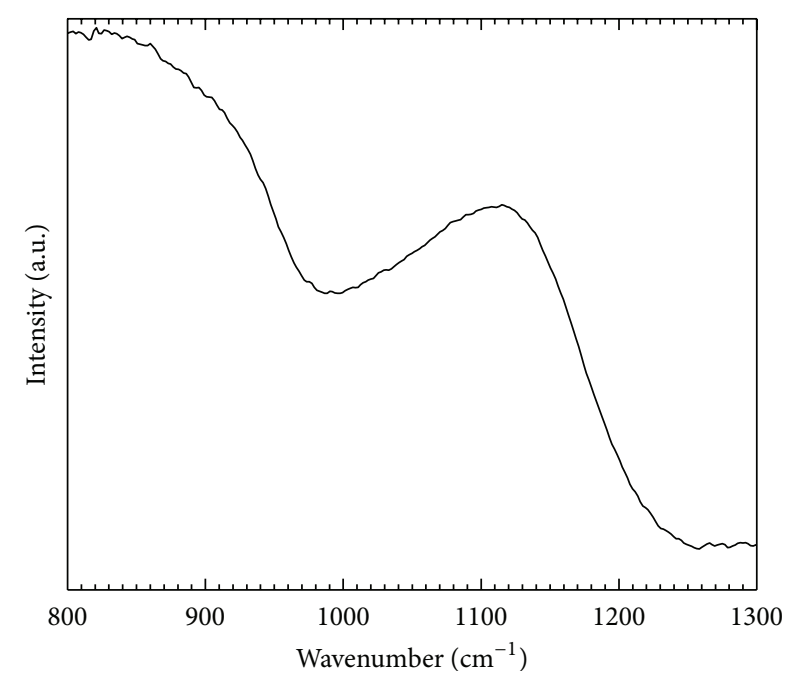

FIGURE 6: FT-IR spectrum of Ti-15Zr-5Nb alloy surface galvanostatically anodized in $1 \mathrm{M} \mathrm{H}_{3} \mathrm{PO}_{4}$ solution for $45 \mathrm{~min}$. at $10 \mathrm{~mA} / \mathrm{cm}^{2}$.

slight higher aggressivity of these solutions; nevertheless, the anodized alloy revealed a very good passive behaviour.

\subsubsection{Electrochemical Behaviour from EIS Measurements.} Nyquist spectra (Zreal versus Zimag) exhibited semicircles with large curvature radii (Figure 10) that describe a capacitive behaviour, a resistant passive film [15, 36, 37]. Because the curvature radii have higher values for the anodized alloy, it results in the fact that its passive film is more resistant. The impedance values for the electrochemical anodized alloy exceed two times the values for the bare alloy; these results indicate a very protective nanostructured layer $[15,36,37]$.

Bode spectra (phase angle versus $\log f$ ) displayed both for bare and anodized alloys (Figure 11) phase angles around the value of $-90^{\circ}$ that represent a capacitive behaviour, a passive film like an electric insulator [16]. Same better behaviour of the anodized alloy than that of the bare one resulted:

(i) in Ringer solution of $\mathrm{pH}=3.21$; the bare alloy presents two phase angles at $-81^{\circ}$ and $-79^{\circ}$, and the anodized one higher values at $-83^{\circ}$ and $-81^{\circ}$ that denote a better capacitive behaviour for the nanostructured alloy;

(ii) in Ringer solution of $\mathrm{pH}=7.58$; the phase angles have values of $-84^{\circ}$ and $-80^{\circ}$ for the bare alloy and of $-86^{\circ}$ and $-82^{\circ}$ for the anodized alloy, namely, a more insulating passive film existing on the nanostructured alloy surface;

(iii) in Ringer solution of $\mathrm{pH}=8.91$; values of $-79^{\circ}$ and $-76^{\circ}$ were registered for the bare alloy and of $-81^{\circ}$ and $-78^{\circ}$ for the anodized alloy.

Those two phase angles indicate a protective film formed by two layers: an inner barrier insulating layer characterized by the higher phase angle in the low frequency range and an outer porous layer represented by the lower phase angle in the intermediate frequency range; through this porous 


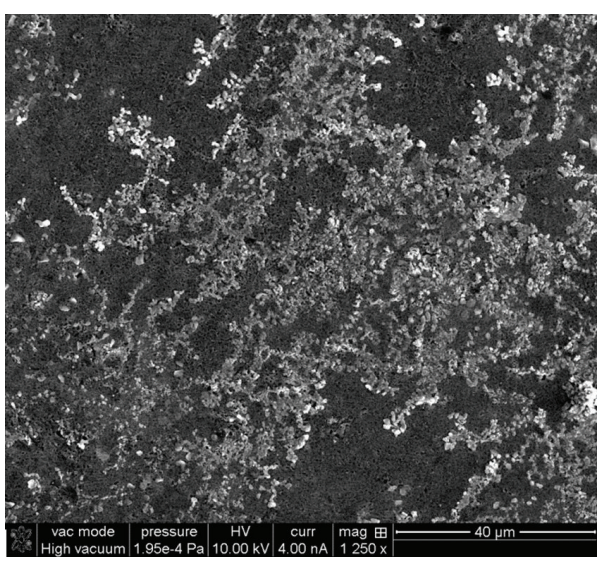

(a)

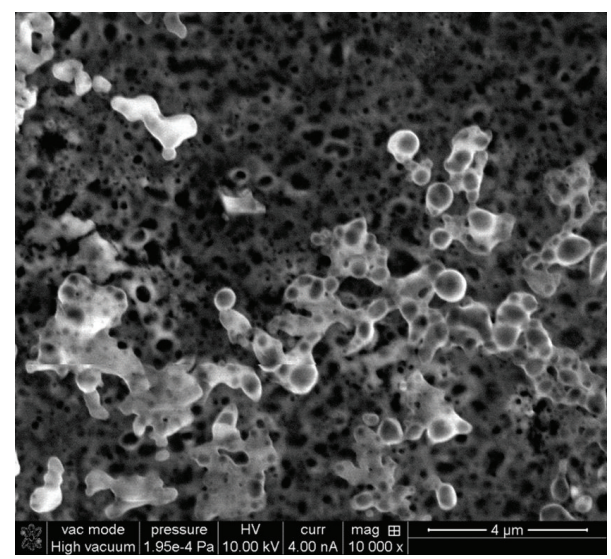

(b)

FIgURE 7: SEM micrographs of Ti-15Zr-5Nb alloy surface galvanostatically anodized in $1 \mathrm{M} \mathrm{H}_{3} \mathrm{PO}_{4}$ solution for $45 \mathrm{~min}$. at $10 \mathrm{~mA} / \mathrm{cm}^{2}$.

TABLE 1: Main electrochemical parameters for bare and anodized Ti-15Zr-5Nb alloys obtained in Ringer solutions at $37^{\circ} \mathrm{C}$.

\begin{tabular}{|c|c|c|c|c|c|}
\hline Ti-15Zr-5Nb & $E_{\text {corr }}(\mathrm{mV})$ & $E_{p}(\mathrm{mV})$ & $\Delta E_{p}(\mathrm{mV})$ & $\left|E_{\text {corr }}-E_{p}\right|(\mathrm{mV})$ & $i_{p}\left(\mu \mathrm{A} / \mathrm{cm}^{2}\right)$ \\
\hline \multicolumn{6}{|c|}{ Ringer $\mathrm{pH}=3.21$} \\
\hline Bare & -350 & -200 & $>2000$ & 150 & 3.9 \\
\hline Anodized & -250 & -150 & $>2000$ & 100 & 1.9 \\
\hline \multicolumn{6}{|c|}{ Ringer $\mathrm{pH}=7.58$} \\
\hline Bare & -200 & 0 & $>2000$ & 200 & 1.0 \\
\hline Anodized & -100 & 0 & $>2000$ & 100 & 0.9 \\
\hline \multicolumn{6}{|c|}{ Ringer $\mathrm{pH}=8.91$} \\
\hline Bare & -350 & -200 & $>2000$ & 150 & 4.1 \\
\hline Anodized & -200 & -100 & $>2000$ & 100 & 2.0 \\
\hline
\end{tabular}

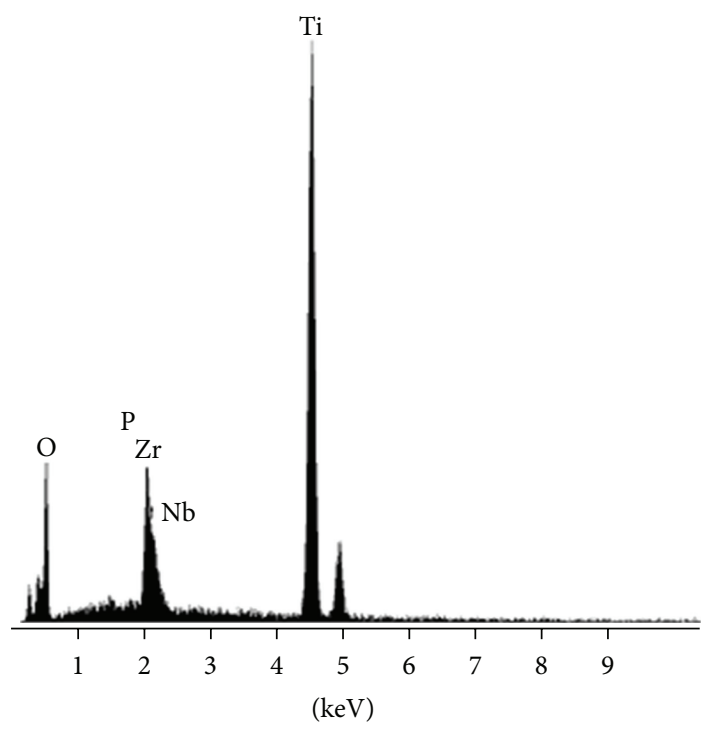

FIGURE 8: EDX spectrum of Ti-15Zr-5Nb alloy surface galvanostatically anodized in $1 \mathrm{M} \mathrm{H}_{3} \mathrm{PO}_{4}$ solution for $45 \mathrm{~min}$.

layer can penetrate the aggressive ions from the physiological solutions and can corrode the inner compact layer, but, in the same time, in these pores can be incorporated calcium and phosphorous ions from biofluid that can provide a good scaffold for the bone cell adhesion [38].

According to the literature $[39,40]$, an electric equivalent circuit with two time constants (Figure 12) was modeled: the first time constant illustrates the inner barrier layer by its resistance, $R_{b}$, and capacitance, $\mathrm{CPE}_{b}$; the second time constant refers to the outer porous layer by its resistance, $R_{p}$, and capacitance, $\mathrm{CPE}_{p}$.

The inner barrier layer resistances, $R_{b}$, and the porous layer resistances, $R_{p}$, of the anodized alloy are higher than those of the bare one (Table 2), showing that the galvanostatic processing generated a more resistant nanolayer; this fact is confirmed by the values of the frequency independent parameters $n 1$ and $n 2$ which are bigger for the processed alloy, indicating a better capacitor $(n=1$ represents an ideal capacitor), namely, superior protective properties [39]. Barrier layer resistances, $R_{b}$, for both bare and anodized alloys have values of about 100 times higher than those of the porous layer, $R_{p}$, proving that the barrier layer assures the alloy good resistance against the physiological solution aggressivity $[41,42]$; on the other hand, lower values of $R_{p}$ denote that the porous layer has inferior protective properties, permitting the diffusion and incorporation of the ions from the biofluid through and into this layer $[36,43]$; thus, this porous layer 

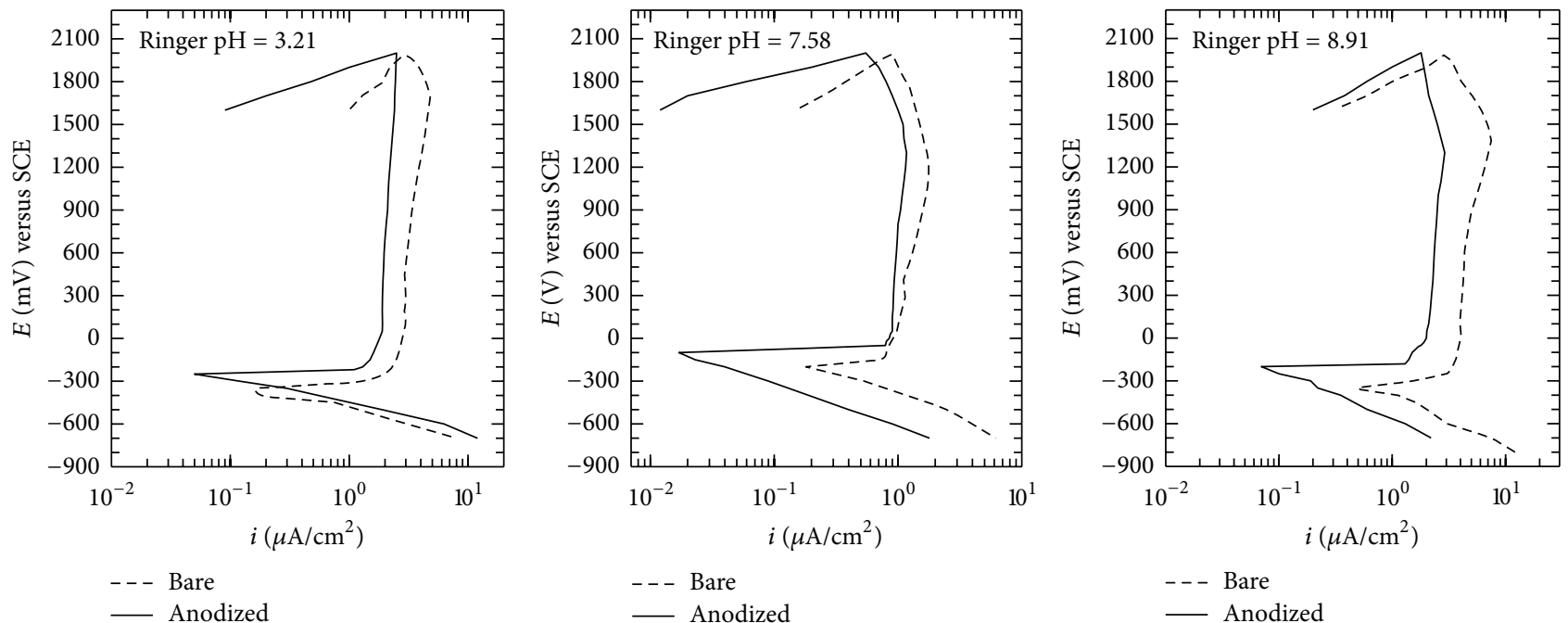

FIgURE 9: Cyclic potentiodynamic curves for bare and anodized Ti-15Zr-5Nb alloys recorded in Ringer solutions at $37^{\circ} \mathrm{C}$.
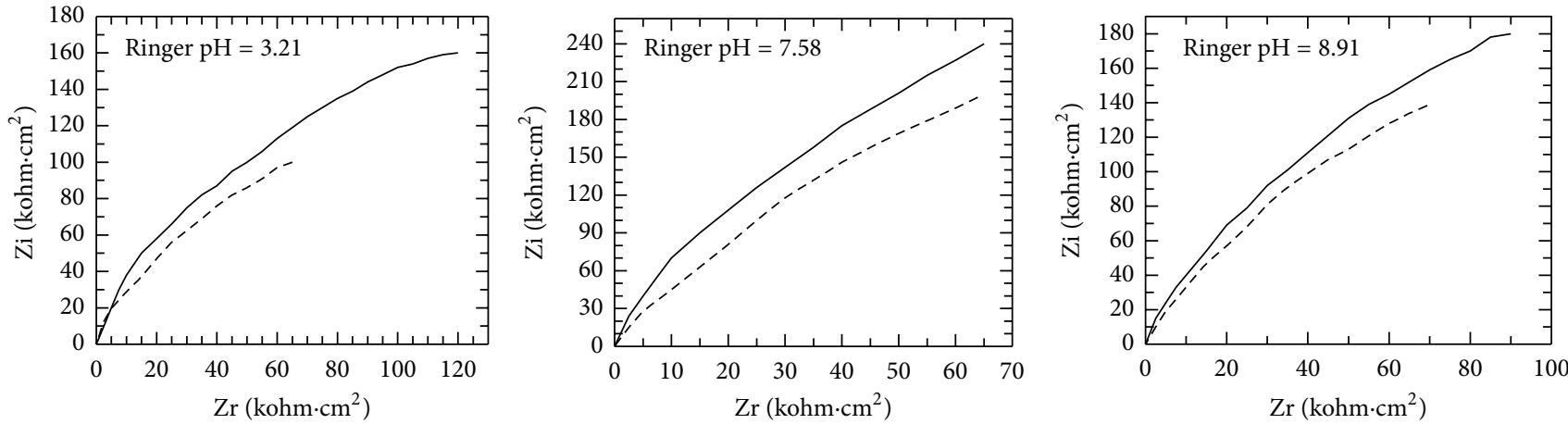

- - - Bare
- Anodized

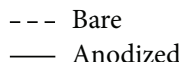

-. - Bare

— Anodized

FIGURE 10: Nyquist spectra for bare and anodized Ti-15Zr-5Nb alloys recorded in Ringer solutions at $37^{\circ} \mathrm{C}$.
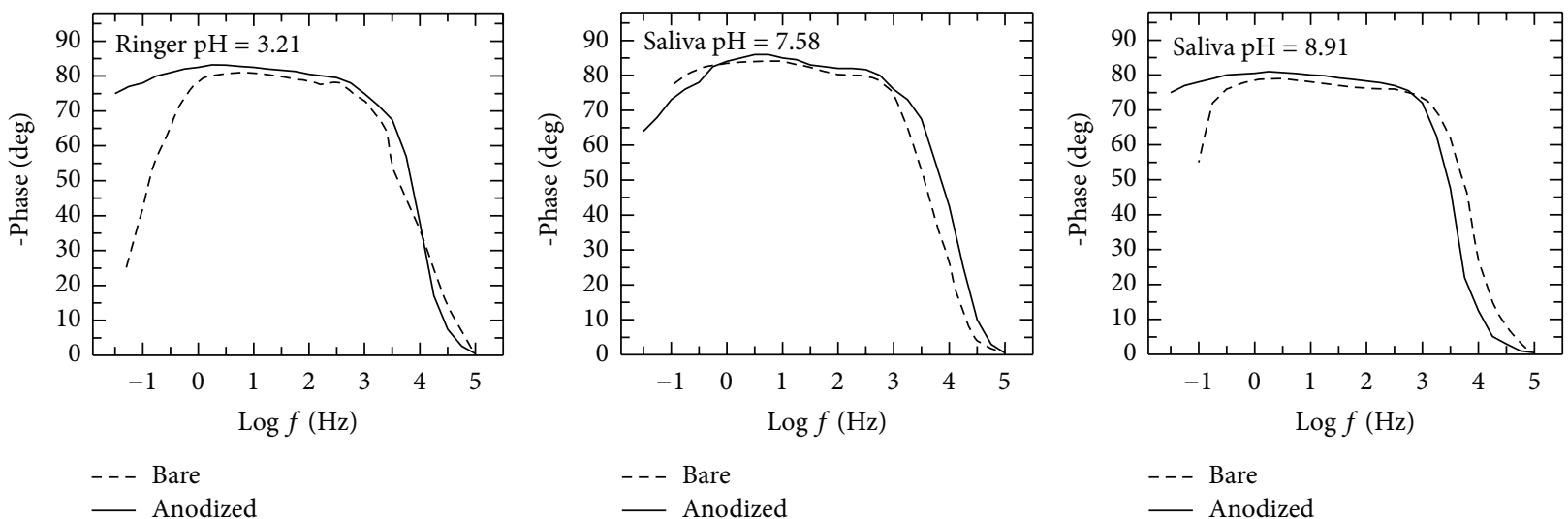

FIgURE 11: Bode spectra for bare and anodized Ti-15Zr-5Nb alloys recorded in Ringer solutions at $37^{\circ} \mathrm{C}$. 
TABLE 2: Fitting parameters of the two time constants electric equivalent circuit.

\begin{tabular}{|c|c|c|c|c|c|c|c|}
\hline Ti-15Zr-5Nb & $R_{\mathrm{sol}}\left(\Omega \cdot \mathrm{cm}^{2}\right)$ & $R_{b}\left(\Omega \cdot \mathrm{cm}^{2}\right)$ & $\mathrm{CPE}_{b}\left(\mathrm{~S} \cdot \mathrm{s}^{n} \cdot \mathrm{cm}^{-2}\right)$ & $n 1$ & $R_{p}\left(\Omega \cdot \mathrm{cm}^{2}\right)$ & $\mathrm{CPE}_{p}\left(\mathrm{~S} \cdot \mathrm{s}^{n} \cdot \mathrm{cm}^{-2}\right)$ & $n 2$ \\
\hline \multicolumn{8}{|c|}{ Ringer $\mathrm{pH}=3.21$} \\
\hline Bare & 14.2 & $7.3 \times 10^{6}$ & $2.2 \times 10^{-6}$ & 0.96 & $1.2 \times 10^{4}$ & $2.5 \times 10^{-5}$ & 0.90 \\
\hline Anodized & 14.8 & $8.7 \times 10^{6}$ & $1.8 \times 10^{-6}$ & 0.98 & $1.5 \times 10^{4}$ & $2.6 \times 10^{-5}$ & 0.91 \\
\hline \multicolumn{8}{|c|}{ Ringer $\mathrm{pH}=7.58$} \\
\hline Bare & 13.6 & $8.1 \times 10^{6}$ & $2.0 \times 10^{-6}$ & 0.97 & $1.8 \times 10^{4}$ & $2.1 \times 10^{-5}$ & 0.91 \\
\hline Anodized & 15.1 & $9.9 \times 10^{6}$ & $1.6 \times 10^{-6}$ & 0.99 & $1.9 \times 10^{4}$ & $2.3 \times 10^{-5}$ & 0.93 \\
\hline \multicolumn{8}{|c|}{ Ringer $\mathrm{pH}=8.91$} \\
\hline Bare & 14.5 & $6.2 \times 10^{6}$ & $2.3 \times 10^{-6}$ & 0.95 & $1.6 \times 10^{4}$ & $2.6 \times 10^{-5}$ & 0.90 \\
\hline Anodized & 14.9 & $8.3 \times 10^{6}$ & $1.9 \times 10^{-6}$ & 0.97 & $1.7 \times 10^{4}$ & $2.7 \times 10^{-5}$ & 0.92 \\
\hline
\end{tabular}

TABLE 3: Main corrosion parameters for bare and anodized Ti-15Zr-5Nb alloys obtained in Ringer solutions at $37^{\circ} \mathrm{C}$.

\begin{tabular}{|c|c|c|c|c|c|}
\hline Ti-15Zr-5Nb & $i_{\text {corr }}\left(\mu \mathrm{A} / \mathrm{cm}^{2}\right)$ & $V_{\text {corr }}(\mu \mathrm{m} / \mathrm{Y})$ & Resistance class & Ion release $\left(\mathrm{ng} / \mathrm{cm}^{2}\right)$ & $R_{p}\left(\mathrm{k} \Omega \cdot \mathrm{cm}^{2}\right)$ \\
\hline \multicolumn{6}{|c|}{ Ringer $\mathrm{pH}=3.21$} \\
\hline Bare & 0.081 & 0.751 & PS & 76.3 & 330 \\
\hline Anodized & 0.029 & 0.269 & PS & 27.33 & 1295 \\
\hline \multicolumn{6}{|c|}{ Ringer $\mathrm{pH}=7.58$} \\
\hline Bare & 0.039 & 0.358 & PS & 36.4 & 397 \\
\hline Anodized & 0.0054 & 0.050 & PS & 5.08 & 3020 \\
\hline \multicolumn{6}{|c|}{ Ringer $\mathrm{pH}=8.91$} \\
\hline Bare & 0.071 & 0.657 & PS & 66.75 & 305 \\
\hline Anodized & 0.019 & 0.175 & PS & 17.78 & 1380 \\
\hline
\end{tabular}

PS: perfect stable.

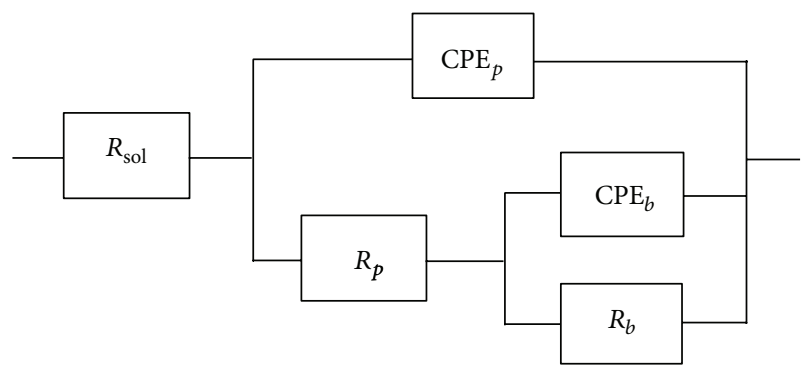

FIGURE 12: Electric equivalent circuit with two time constants.

provides the necessary conditions for the interactions of the alloy with human fluid, namely, the bioactivity of the surface layer [43].

3.3. Corrosion Stability of the Bare and Anodized Alloys in Ringer Solutions of Different $p H$ Values. The corrosion stability of the bare and anodized alloys was appreciated from the values of the corrosion current densities, $i_{\text {corr }}$, corrosion, $V_{\text {corr }}$, and ion release rates and polarization resistances, $R_{p}$ (Table 3), obtained from Tafel representations. The main corrosion parameters have better values for the anodized alloy than those for the bare one:

(i) corrosion current densities, $i_{\text {corr }}$, corrosion, $V_{\text {corr }}$, and ion release rates have lower values that show a better resistance to corrosion and implicitly a more reduced quantity of ions released in biofluid, namely, a lower toxicity $[21,22]$

(ii) polarization resistance, $R_{p}$, has higher values (of about 10 times, order $\mathrm{M} \Omega \cdot \mathrm{cm}^{2}$ ) that prove a more resistant layer $[23,25]$.

Though, in acid and alkaline Ringer solutions, both the bare and the anodized alloys have a little higher corrosion rates, their values are placed in the "Perfect Stable" resistance class, indicating a very good anticorrosive resistance. The best corrosion resistance for the processed alloy resulted in neutral Ringer solution, normal conditions from the human body.

3.4. Long-Term Behaviour of the Bare and Anodized Alloys in Ringer Solutions of Different $p H$ Values. The long-term behaviour of the bare and anodized alloys was determined from the monitoring of the open circuit potentials, $E_{\mathrm{oc}}$, and corresponding open circuit potential gradients, $\Delta E_{\mathrm{oc}}$, for 1500 soaking hours in Ringer solutions of acid (3.21), neutral (7.58), and alkaline (8.91) pH values (Figure 13).

The open circuit potentials for the anodized alloy shifted to more positive values in time, showing the increase of its protective nanolayer thickness [23]. $E_{\mathrm{oc}}$ had more electropositive values for the anodized alloy than those for the bare one, which reveal more protective nanolayers [15, 16, 23]. Also, these potentials reached almost constant values after about $700 \mathrm{~h}$, demonstrating more resistant, stable state [23].

The open circuit potential gradients, $\Delta E_{\text {oc }}$, have very low values (Table 4 ) that cannot generate galvanic corrosion. 

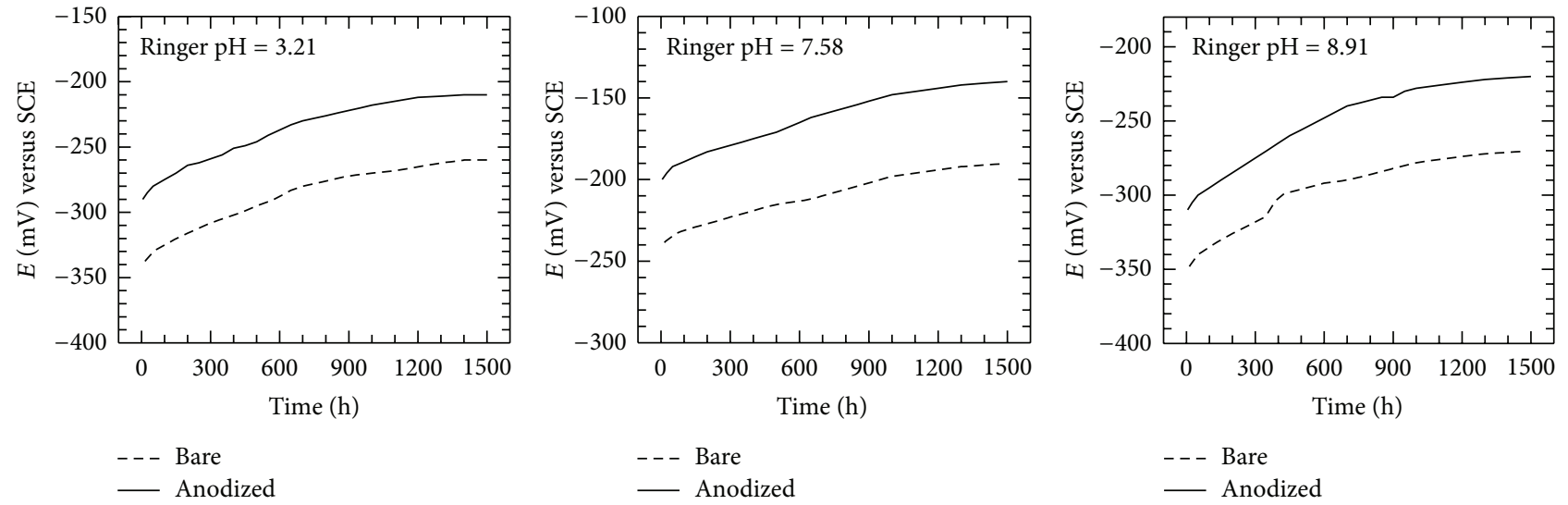

Figure 13: Monitoring of the open circuit potentials for bare and anodized Ti-15Zr-5Nb alloy in Ringer solutions at $37^{\circ} \mathrm{C}$.

TAble 4: Potential gradients for bare and anodized Ti-15Zr-5Nb alloys obtained in Ringer solutions at $37^{\circ} \mathrm{C}$.

\begin{tabular}{lcccc}
\hline Ti-15Zr-5Nb & Time $(\mathrm{h})$ & $\Delta E_{\mathrm{oc1}}(\mathrm{mV})$ & $\Delta E_{\mathrm{oc} 2}(\mathrm{mV})$ & $\Delta E_{\mathrm{oc} 3}(\mathrm{mV})$ \\
\hline \multirow{4}{*}{ Bare } & 24 & -98 & +10 & +108 \\
& 500 & -80 & +10 & +81 \\
& 1000 & -72 & +8 & +80 \\
& 1500 & -70 & +10 & +80 \\
\hline \multirow{4}{*}{ Anodized } & 24 & -89 & +20 & +20 \\
& 500 & -75 & +10 & +41 \\
& 1000 & -70 & +10 & +80 \\
& 1500 & -70 & +10 & +80 \\
\hline
\end{tabular}

Many authors $[44,45]$ showed that only differences of $600-$ $700 \mathrm{mV}$ can initiate and maintain galvanic cells; therefore, both the bare and the anodized alloys cannot corrode by galvanic corrosion, even in the case of large differences in the biofluid $\mathrm{pH}$ values between 3.21 and $8.91\left(\Delta E_{\mathrm{oc} 2}\right)$ that could appear on the alloy surface in its long-term "working life" as implant.

\section{Conclusions}

The new Ti-15Zr-5Nb alloy surface was nanostructured by galvanostatic anodization in $0.3 \mathrm{M} \mathrm{H}_{3} \mathrm{PO}_{4}$ solution. The obtained layer has a nanotube-like porosity, revealed by SEM, and it is formed of anatase-like small crystallites, with added phosphorus as phosphotitanate, determined by Raman spectroscopy, FT-IR, and EDX analyses; this composition can stimulate the formation of the bone and the porosity can offer a good scaffold for the bone cell attachment. Cyclic potentiodynamic curves make evident a nobler behaviour of the anodized alloy than that of the bare one, as a result of the existence of the nanostructured layer that improves the protective properties of the native passive film by its thickening. EIS spectra revealed a better capacitive behaviour, a more insulating protective film electrodeposited on the alloy surface; the nanostructured film is formed by two layers: an inner barrier layer that assures the alloy very good anticorrosive resistance and an outer porous layer that can provide the good conditions for the bone cell adhesion. Corrosion and ion release rates have lower values showing a better resistance to corrosion and implicitly a more reduced quantity of ions released in biofluid, namely, a lower toxicity of the anodized alloy. The open circuit potentials for the nanostructured alloy shifted to more positive values in time, indicating the increase of its protective layer thickness. The open circuit potential gradients have very low values that cannot generate galvanic corrosion.

\section{Acknowledgments}

This work was supported by Romanian UEFISCDI, Project no. IDEI 278/2010. Also, support of the EU (ERDF) and Romanian Government Infrastructure POS-CCE O 2.2.1 project INFRANANOCHEM no. 19/2009 is gratefully acknowledged.

\section{References}

[1] P. K. Zysset, X. E. Guo, C. E. Hoffler, K. E. Moore, and S. A. Goldstein, "Mechanical properties of human trabecular bone lamellae quantified by nanoindentation," Technology and Health Care, vol. 6, no. 5-6, pp. 429-432, 1998.

[2] E. Eisenbarth, D. Velten, M. Müller, R. Thull, and J. Breme, "Biocompatibility of $\beta$-stabilizing elements of titanium alloys," Biomaterials, vol. 25, no. 26, pp. 5705-5713, 2004.

[3] P. Thomsen, C. Larsson, L. E. Ericson, L. Sennerby, J. Lausmaa, and B. Kasemo, "Structure of the interface between rabbit cortical bone and implants of gold, zirconium and titanium," Journal of Materials Science: Materials in Medicine, vol. 8, no. 11, pp. 653-665, 1997.

[4] S. Tanaka, H. Tobimatsu, Y. Maruyama, T. Tanaki, and G. Jerkiewicz, "Preparation and characterization of microporous layers on titanium," ACS Applied Materials \& Interfaces, vol. 1, no. 9, pp. 2312-2319, 2009.

[5] A. Zeller, A. Musyanovych, M. Kappl et al., "Nanostructured coatings by adhesion of phosphonated polystyrene particles onto titanium surface for implant material applications," ACS Applied Materials \& Interfaces, vol. 2, no. 8, pp. 2421-2428, 2010. 
[6] A. Nakahira, T. Kubo, and C. Numako, " $\mathrm{TiO}_{2}$-derived titanate nanotubes by hydrothermal process with acid treatments and their microstructural evaluation," ACS Applied Materials \& Interfaces, vol. 2, no. 9, pp. 2611-2616, 2010.

[7] P. He, J. Tao, J. Xue, and Y. Chen, "Cytotoxicity property of nano$\mathrm{TiO}_{2}$ sol and nano-TiO 2 powder," Journal of Nanomaterials, vol. 2011, Article ID 261605, 8 pages, 2011.

[8] J. Park, S. Bauer, K. Von Der Mark, and P. Schmuki, "Nanosize and vitality: $\mathrm{TiO}_{2}$ nanotube diameter directs cell fate," Nano Letters, vol. 7, no. 6, pp. 1686-1691, 2007.

[9] T. Dey, P. Roy, B. Fabry, and P. Schmuki, "Anodic mesoporous $\mathrm{TiO}_{2}$ layer on $\mathrm{Ti}$ for enhanced formation of biomimetic hydroxyapatite," Acta Biomaterialia, vol. 7, no. 4, pp. 1873-1879, 2011.

[10] H. H. Park, I. S. Park, K. S. Kim et al., "Bioactive and electrochemical characterization of $\mathrm{TiO}_{2}$ nanotubes on titanium via anodic oxidation," Electrochimica Acta, vol. 55, no. 20, pp. 6109$6114,2010$.

[11] Y. Shibata, D. Suzuki, S. Omori et al., "The characteristics of in vitro biological activity of titanium surfaces anodically oxidized in chloride solutions," Biomaterials, vol. 31, no. 33, pp. 8546$8555,2010$.

[12] F. M. B. Hassan, H. Nanjo, S. Venkatachalam, M. Kanakubo, and T. Ebina, "Effect of the solvent on growth of titania nanotubes prepared by anodization of Ti in HCl," Electrochimica Acta, vol. 55, no. 9, pp. 3130-3137, 2010.

[13] E. Peláez-Abellán, L. Rocha-Sousa, W. D. Müller, and A. C. Guastaldi, "Electrochemical stability of anodic titanium oxide films grown at potentials higher than $3 \mathrm{~V}$ in a simulated physiological solution," Corrosion Science, vol. 49, no. 3, pp. 1645-1655, 2007.

[14] J. C. Mirza Rosca, M. V. Popa, E. Vasilescu, P. Drob, C. Vasilescu, and S. I. Drob, "Effects of electrochemical and thermal oxidation on the behaviour of some biomaterials in simulated body fluids," Revue Roumaine de Chimie, vol. 55, no. 10, pp. 639-646, 2010.

[15] R. Narayanan and S. K. Seshadri, "Phosphoric acid anodization of Ti-6Al-4V-structural and corrosion aspects," Corrosion Science, vol. 49, no. 2, pp. 542-558, 2007.

[16] S. K. Poznyak, A. D. Lisenkov, M. G. S. Ferreira, A. I. Kulak, and M. L. Zheludkevich, "Impedance behaviour of anodic $\mathrm{TiO}_{2}$ films prepared by galvanostatic anodisation and powerful pulsed discharge in electrolyte," Electrochimica Acta, vol. 76, pp. 453-461, 2012.

[17] Z. Li, C. Ning, D. Ding, H. Liu, and L. Huang, "Biological properties of Ti-Nb-Zr-O nanostructures grown on Ti35Nb5Z Zr alloy," Journal of Nanomaterials, vol. 2012, Article ID 834042, 7 pages, 2012.

[18] T. Hanawa, "In vivo metallic biomaterials and surface modification," Materials Science and Engineering A, vol. 267, no. 2, pp. 260-266, 1999.

[19] Z. Cai, H. Nakajima, M. Woldu, A. Berglund, M. Bergman, and T. Okabe, "In vitro corrosion resistance of titanium made using different fabrication methods," Biomaterials, vol. 20, no. 2, pp. 183-190, 1999.

[20] R. Van Noort, "Titanium: the implant material of today," Journal of Materials Science, vol. 22, no. 11, pp. 3801-3811, 1987.

[21] E. Vasilescu, P. Drob, D. Raducanu et al., "Effect of thermomechanical processing on the corrosion resistance of Ti6Al4V alloys in biofluids," Corrosion Science, vol. 51, no. 12, pp. 28852896, 2009.
[22] E. Vasilescu, P. Drob, D. Raducanu et al., "In vitro biocompatibility and corrosion resistance of a new implant titanium base alloy," Journal of Materials Science: Materials in Medicine, vol. 21, no. 6, pp. 1959-1968, 2010.

[23] D. J. Blackwood, A. W. C. Chua, K. H. W. Seah, R. Thampuran, and S. H. Teoh, "Corrosion behaviour of porous titaniumgraphite composites designed for surgical implants," Corrosion Science, vol. 42, no. 3, pp. 481-503, 2000.

[24] M. V. Popa, I. Demetrescu, E. Vasilescu et al., "Corrosion susceptibility of implant materials Ti-5Al-4V and Ti-6Al-4Fe in artificial extra-cellular fluids," Electrochimica Acta, vol. 49, no. 13, pp. 2113-2121, 2004.

[25] V. D. Cojocaru, D. Raducanu, I. Cinca et al., "Improvement of the corrosion resistance and structural and mechanical properties of a titanium base alloy by thermo-mechanical processing," Materials and Corrosion, 2012.

[26] M. V. Popa, I. Demetrescu, S. H. Suh et al., "Monitoring of titanium base alloys-biofluids interface," Bioelectrochemistry, vol. 71, no. 2, pp. 126-134, 2007.

[27] V. G. Pol, S. H. Kang, J. M. Calderon-Moreno, C. S. Johnson, and M. M. Thackeray, "Autogenic reactions for preparing carbonencapsulated, nanoparticulate $\mathrm{TiO}_{2}$ electrodes for lithium-ion batteries," Journal of Power Sources, vol. 195, no. 15, pp. 50395043, 2010.

[28] H. C. Choi, Y. M. Jung, and S. B. Kim, "Size effects in the Raman spectra of $\mathrm{TiO}_{2}$ nanoparticles," Vibrational Spectroscopy, vol. 37, no. 1, pp. 33-38, 2005.

[29] M. V. Popa, J. M. C. Moreno, M. Popa et al., "Electrochemical deposition of bioactive coatings on Ti and Ti-6Al-4V surfaces," Surface and Coatings Technology, vol. 205, no. 20, pp. 47764783, 2011.

[30] M. Popa, E. Vasilescu, P. Drob et al., "Biomimetic deposition of nanocrystalline hydroxyapatite coatings on non-allergic Ti$20 \mathrm{Nb}-10 \mathrm{Zr}-5 \mathrm{Ta}$ and stability of the coated alloy in body fluids," Journal of American Ceramic Society, vol. 95, no. 12, pp. 38073814, 2012.

[31] P. N. de Aza, F. Guitian, C. Santos, S. de Aza, R. Cusco, and L. Artus, "Vibrational properties of calcium phosphate compounds. 2. Comparison between hydroxyapatite and $\beta$ tricalcium phosphate," Chemistry of Materials, vol. 9, no. 4, pp. 916-922, 1997.

[32] Y. Zhao, G. Zhu, X. Jiao, W. Liu, and W. Pang, "Template synthesis and characterization of a new 2-D layered titanium phosphate," Journal of Materials Chemistry, vol. 10, no. 2, pp. 463-467, 2000.

[33] T. Masui, H. Hirai, N. Imanaka, and G. Y. Adachi, "New sunscreen materials based on amorphous cerium and titanium phosphate," Journal of Alloys and Compounds, vol. 408-412, pp. 1141-1144, 2006.

[34] H. J. De Jager and L. C. Prinsloo, "The dehydration of phosphates monitored by DSC/TGA and in situ Raman spectroscopy," Thermochimica Acta, vol. 376, no. 2, pp. 187-196, 2001.

[35] M. P. Neupane, Y. K. Kim, I. S. Park, S. J. Lee, M. H. Lee, and T. S. Bae, "Effect of electrolyte $\mathrm{pH}$ on the structure and in vitro osteoblasts response to anodic titanium oxide," Metals and Materials International, vol. 14, no. 5, pp. 607-613, 2008.

[36] S. L. Assis, S. Wolynec, and I. Costa, "The electrochemical behaviour of Ti-13Nb-13Zr alloy in various solutions," Materials and Corrosion, vol. 59, no. 9, pp. 739-743, 2008.

[37] A. Robin, O. A. S. Carvalho, S. G. Schneider, and S. Schneider, "Corrosion behavior of Ti-xNb-13Zr alloys in Ringer's solution," Materials and Corrosion, vol. 59, no. 12, pp. 929-933, 2008. 
[38] R. Z. Legeros, S. Lin, R. Rohanizadeh, D. Mijares, and J. P. Legeros, "Biphasic calcium phosphate bioceramics: preparation, properties and applications," Journal of Materials Science: Materials in Medicine, vol. 14, no. 3, pp. 201-209, 2003.

[39] Y.-H. Jeong, H.-C. Choe, and W. A. Brantley, "Electrochemical and surface behavior of hydroxyapatite/Ti film on nanotubular Ti-35Nb-xZr alloys," Applied Surface Science, vol. 258, no. 6, pp. 2129-2136, 2012.

[40] M. T. Woldemedhin, D. Raabe, and A. W. Hassel, "Characterization of thin anodic oxides of Ti-Nb alloys by electrochemical impedance spectroscopy," Electrochimica Acta, vol. 82, pp. 324$332,2012$.

[41] I. Milošev, T. Kosec, and H. H. Strehblow, "XPS and EIS study of the passive film formed on orthopaedic Ti-6Al-7Nb alloy in Hank's physiological solution," Electrochimica Acta, vol. 53, no. 9, pp. 3547-3558, 2008.

[42] V. A. Alves, R. Q. Reis, I. C. B. Santos et al., "In situ impedance spectroscopy study of the electrochemical corrosion of $\mathrm{Ti}$ and Ti-6Al-4V in simulated body fluid at $25^{\circ} \mathrm{C}$ and $37^{\circ} \mathrm{C}$," Corrosion Science, vol. 51, no. 10, pp. 2473-2482, 2009.

[43] S. Tamilselvi and N. Rajendran, "In vitro corrosion behaviour of Ti-5Al-2Nb-1Ta alloy in Hanks solution," Materials and Corrosion, vol. 58, no. 4, pp. 285-289, 2007.

[44] E. Blasco-Tamarit, A. Igual-Muñoz, J. G. Antón, and D. M. García-García, "Galvanic corrosion of titanium coupled to welded titanium in $\mathrm{LiBr}$ solutions at different temperatures," Corrosion Science, vol. 51, no. 5, pp. 1095-1102, 2009.

[45] G. Sheela, M. Ramasamy, C. R. K. Rao, and M. Pushpavanam, "Electrochemical assessment on corrosion behaviour of electrochemically joined dissimilar metal joints," Bulletin of Electrochemistry, vol. 17, no. 8, pp. 347-350, 2001. 

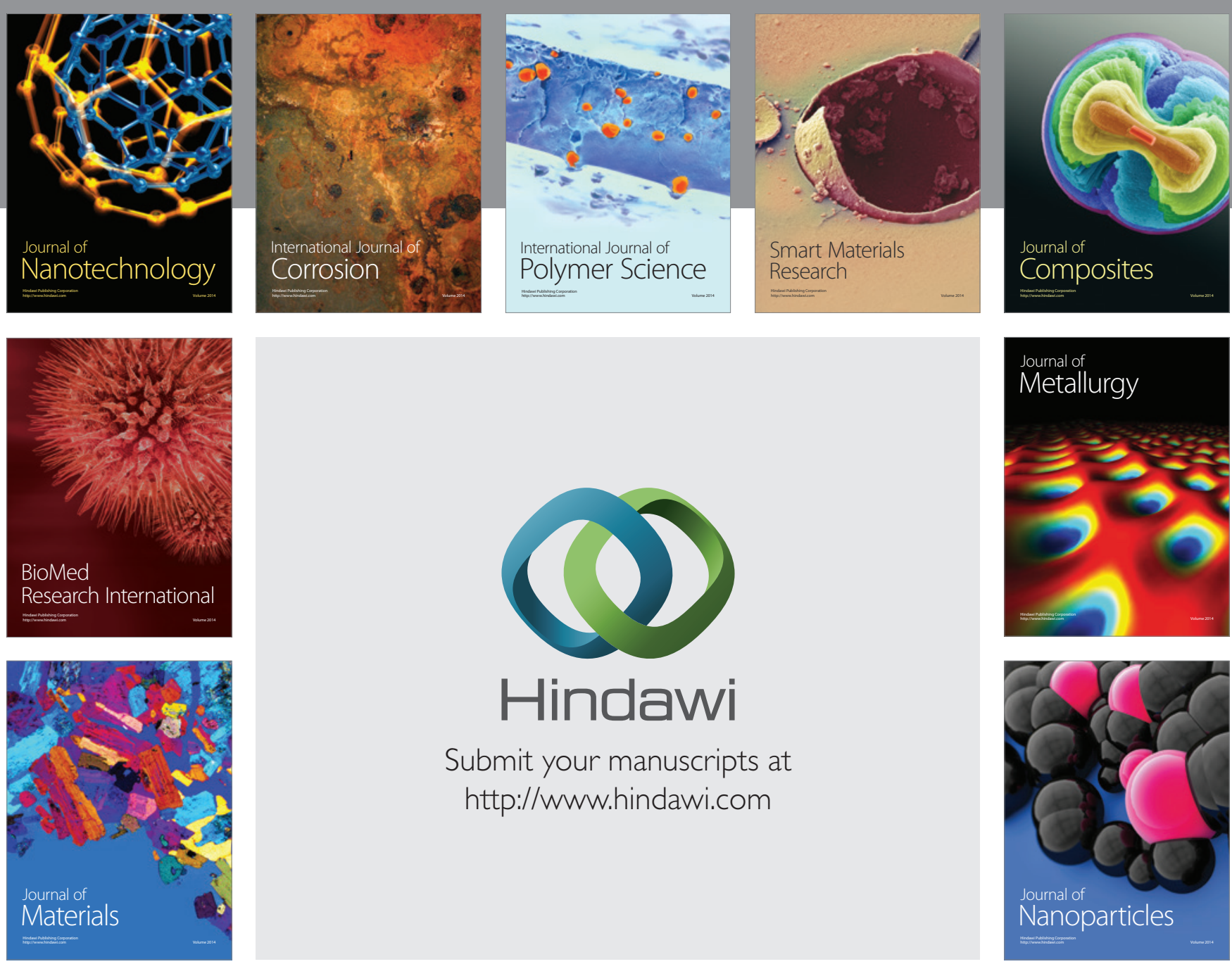

Submit your manuscripts at http://www.hindawi.com
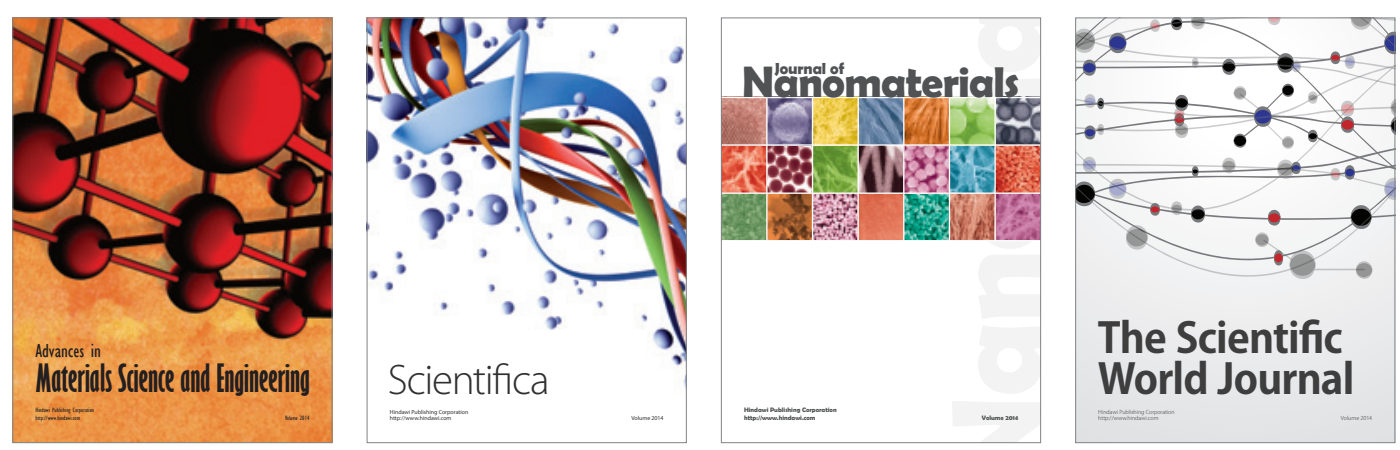

\section{The Scientific World Journal}
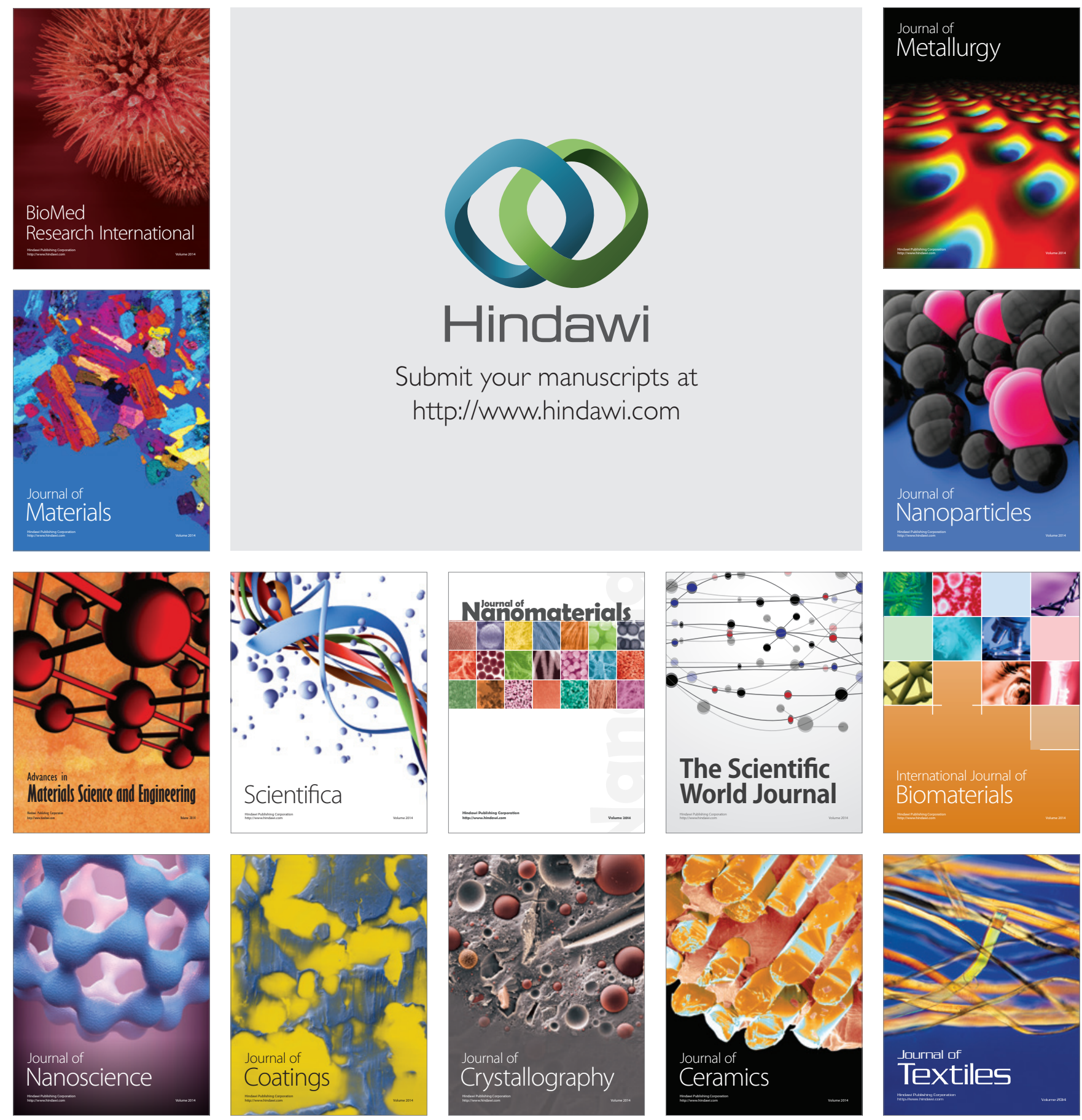